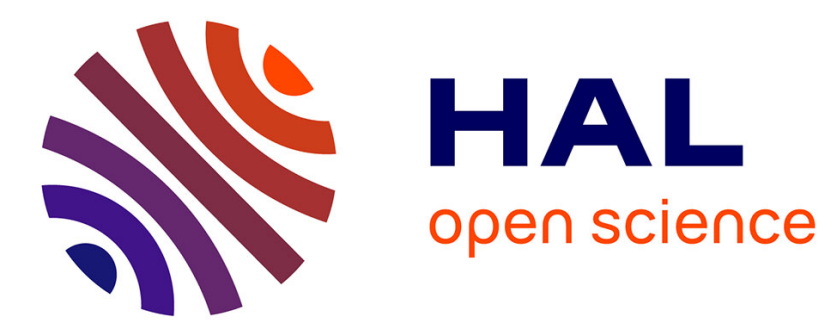

\title{
Fe(II)-Fe(III)-Bearing Phases As a Mineralogical Control on the Heterogeneity of Arsenic in Southeast Asian Groundwater
}

\author{
André Burnol, Laurent Charlet
}

\section{- To cite this version:}

André Burnol, Laurent Charlet. Fe(II)-Fe(III)-Bearing Phases As a Mineralogical Control on the Heterogeneity of Arsenic in Southeast Asian Groundwater. Environmental Science and Technology, 2010, 44 (19), pp.7541-7547. 10.1021/es100280h . hal-00521988

\section{HAL Id: hal-00521988 https: / hal-brgm.archives-ouvertes.fr/hal-00521988}

Submitted on 7 Aug 2015

HAL is a multi-disciplinary open access archive for the deposit and dissemination of scientific research documents, whether they are published or not. The documents may come from teaching and research institutions in France or abroad, or from public or private research centers.
L'archive ouverte pluridisciplinaire HAL, est destinée au dépôt et à la diffusion de documents scientifiques de niveau recherche, publiés ou non, émanant des établissements d'enseignement et de recherche français ou étrangers, des laboratoires publics ou privés. 


\title{
Fe(II)-Fe(III)-bearing Phases as a Mineralogical
}

\section{Control on the Heterogeneity of Arsenic in Southeast}

\section{Asian Groundwater}

\author{
ANDRE BURNOL ${ }^{\xi t^{*}}$, LAURENT CHARLET $T^{\S}$ \\ §̧LGIT-OSUG, University of Grenoble-I, BP 53, F-38041 Grenoble Cedex 9, France. \\ ¥ BRGM, Bureau de Recherches Géologiques et Minières, Environment and Process Division, 3, avenue Claude Guillemin, BP 36009, 45060 Orléans \\ Cedex 2, France
}

In preparation for Environmental Science \& Technology

*Corresponding author

Phone: +33 238644 647; fax: +33 238643 062; e-mail address: a.burnol@brgm.fr 


\begin{abstract}
(word limit: 150-200 words) (192 words)
\end{abstract}
Although groundwater arsenic constitutes a major hazard to the health of the people of Southeast Asia, the exact mineralogical origin of the arsenic in these fluvial aquifers is still under debate. Fe(III) oxides are the dominant hosts of mobilizable arsenic in the sediments, with the role of secondary Fe(II)-bearing phases like mackinawite, siderite, vivianite, magnetite and carbonate green rust (fougerite) still unclear. Based on published field data from Chakdaha (India), the importance of the phases for arsenic mobility is evaluated quantitatively using models of growing complexity. Arsenic heterogeneity can be explained by the presence of two contrasted redox zones in the aquifers, with Fe(III) oxides being the dominant sorbent for arsenic in the less reduced zones and Fe(II) sulfides and/or Fe(II) carbonates being the solid-phase hosts for arsenic under more reduced conditions below impermeable soils or close to rivers where sulfate is reduced. A 1D reactive transport model which simulates the transition between the two environments has been developed and compared to field data. The results show that microbial sulfate reduction followed by abiotic and/or biotic reduction of As(III)-bearing iron oxides accounts for the spatial heterogeneity of arsenic in such reduced aquifers. 


\section{TOC Art}

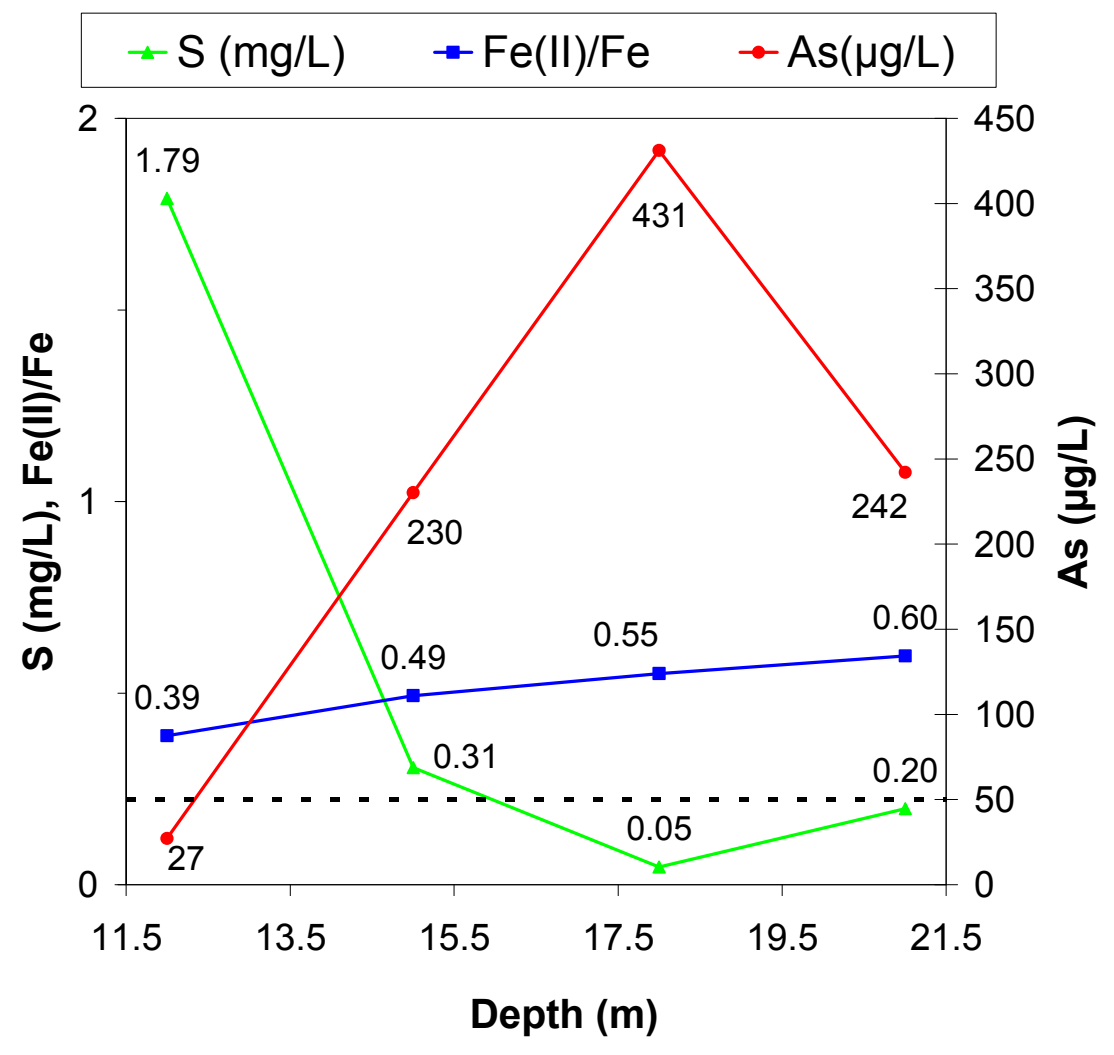


(less than 7000 words) (4480 words with references, 2 Tables, 4 Figures)

\section{Introduction (2 double spaced pages with $<20$ references)}

The spatial heterogeneity of arsenic in shallow groundwater is well documented in many fluvial regions of Southeast Asia and occurs on very small scales with high arsenic concentrations (>100 $\mu \mathrm{g} / \mathrm{L}$ ) commonly being found within tens of meters of low concentrations, i.e. below $50 \mu \mathrm{g} / \mathrm{L}$, the drinking water standard in those areas. It reflects local heterogeneities in the water recharge, water chemistry and sediment properties inherent to a young depositional floodplain environment.

The most widely accepted mechanism causing high aqueous arsenic concentrations in Southeast Asian aquifers is the microbial reductive dissolution of iron (hydr)oxides and the concomitant release of arsenic (1). The origin of the organic matter that drives such aquifers toward reducing conditions is, however, still under debate. Moreover, there is an observed decoupling of iron and arsenic release in both the laboratory (2-4) and the field (1). This poor As-Fe correlation could be explained by various scenarios, such as (i) a biotic reduction of $\mathrm{As}(\mathrm{V})$ to $\mathrm{As}(\mathrm{III})$ which sorbs more weakly onto iron oxyhydroxides (4), (ii) a precipitation of different secondary Fe(II) phases after the reductive dissolution of Fe(III) phases (5), (iii) a weaker sorption of arsenic by the secondary Fe(II) phases ((6) and references therein).

The combination of local hydrology and geochemistry in those aquifers results in two contrasted geochemical environments: a moderately reduced environment characterized by low $\mathrm{Fe}(\mathrm{II}) / \mathrm{Fe}$ ratios with relatively high sulfate and low arsenic concentrations $(<50 \mu \mathrm{g} / \mathrm{L} \mathrm{As})$, and a more reduced (hereafter termed "anoxic") environment characterized by higher $\mathrm{Fe}(\mathrm{II}) / \mathrm{Fe}$ ratios with lower sulfate and higher As concentrations. These two environments have been observed along the Mekong River in Cambodia (7-9), along the Red River in Vietnam (10), along a stream at the $\mathrm{K}$ site in Araihazar, Bangladesh $(11,12)$ and along the Hooghly River in Chakdaha, India $(13,14)$ (Figures 2SI and 3SI). 
In these anoxic environments, arsenic mobility would be controlled by the nature and distribution of secondary Fe(II) or mixed $\mathrm{Fe}(\mathrm{II}) / \mathrm{Fe}(\mathrm{III})$ phases like mackinawite $\mathrm{Fe}(\mathrm{II}) \mathrm{S}$, magnetite $\mathrm{Fe}(\mathrm{II}) \mathrm{Fe}(\mathrm{III})_{2} \mathrm{O}_{4}$, fougerite $\mathrm{Fe}(\mathrm{II})_{4} \mathrm{Fe}(\mathrm{III})_{2}(\mathrm{OH})_{12} \mathrm{CO}_{3} \cdot 2 \mathrm{H}_{2} \mathrm{O}$ (the mineral analogue of carbonate green rust), siderite $\mathrm{Fe}(\mathrm{II}) \mathrm{CO}_{3}$ and vivianite $\mathrm{Fe}(\mathrm{II})_{3}\left(\mathrm{PO}_{4}\right)_{2} .8 \mathrm{H}_{2} \mathrm{O}(15-17)$.

The aim of the present paper is to infer from Chakdaha data (India) different scenarios of arsenic release using models of growing complexity like $\mathrm{Kd}$ sorption, surface complexation and 1D reactive transport models.

\section{Models}

Iron(III) surface complexation model. Geochemical speciation and sorption were performed with PHREEQC version 2.15 (18) using the WATEQ4F database (19). The protonation constants of arsenite, being consistent with the sorption data calculated by Dixit and Hering (20), were extracted from the MINEQL V4.5 database (21). Only arsenite is considered because arsenate reduction is expected to precede crystallised iron (e.g. goethite, hematite) and sulphate reduction on a thermodynamic basis (9). The interaction between arsenite and iron(III) surface is described by the two-layer surface complexation model from Dzombak and Morel (22) with only one type of adsorption site being considered, i.e. the weak sites $\equiv(\mathrm{w}) \mathrm{FeOH}$ (Table 1). Campbell et al. (23) estimated that the maximum surface site density for arsenic onto ferric hydroxides is $[\equiv(w) F e O H]=$ $0.117 \mathrm{Fe}_{\mathrm{T}}$ with $\mathrm{Fe}_{\mathrm{T}}$ the total solid $\mathrm{Fe}$ concentration. The amount of extractable iron in the sediments ranged from 1.6 to 9.7 wt.\% at the Chakdaha site (14) but only a fraction of this iron is contained in mineral phases with available surface sites for arsenic. This available fraction, which includes amorphous phases (e.g. ferrihydrite) and also more crystalline Fe minerals (e.g. hematite, goethite), can be approximated by the reducible iron pool of the sediment, typically 10 to $20 \%$ of the solid phase iron, as opposed to the recalcitrant fraction (e.g. Fe incorporated in silicate minerals) (24). The 
reducible Fe fraction in our model is assumed to be $20 \%$ of the total iron, i.e. 0.2 wt.\% supposing 1 wt.\% of iron in sediment.

1D generic reactive transport model. Coupling the geochemical reactions with a constant $1 \mathrm{D}$ advective flow was performed with PHREEQC version 2.15 (18) using the WATEQ4F database (19). A high pore velocity of $5 \mathrm{~cm} /$ day (see SI), i.e. $5.810^{-7} \mathrm{~m} / \mathrm{s}$, is selected for simulating a generic 1D flow path from an area recharge to a depth range (e.g. the Wells I3-5-6-7).

The model's reaction processes at local equilibrium are aqueous speciation, surface complexation onto iron oxide (Table 1) and mineral dissolution/precipitation. Microbially mediated terminal electron accepting processes (TEAPs) are included in the model under kinetic constraints. A first order dependency for surface-complexed sulfide concentrations with respect to the abiotic reduction of iron could be considered (Table 2). The sorption of arsenic onto secondary phases (siderite or mackinawite) is included in the model using the $\mathrm{Kd}$ at $\mathrm{pH} 7$ (Table 1) and a very high kinetics (Table 2, SI). The Michaelis-Menten and Monod kinetic approaches are traditionally used for modeling TEAPs coupled with transport (25). A well-known shortcoming of this approach is that it does not account for the complete competitive exclusion or/and the thermodynamic feasibility of these TEAPs $(26,27)$. In this generic study, the total rate of organic carbon oxidation ( $\mathrm{Rc})$ is determined independently from the concentration of species other than organic carbon. Rc is assumed to be representative of the average reactivity of the sedimentary organic carbon over the vertical range of interest and is broken down into the contributions of individual metabolic pathways represented by nitrate, sulfate and/or iron reduction (see SI). The sequential use of terminal electron acceptors based on differences in their redox potential can be simulated by defining critical concentrations of electron acceptors below which the model shifts to the next available electron acceptor. The limiting concentrations for $\mathrm{NO}_{3}{ }^{-}, \mathrm{SO}_{4}^{--}, \mathrm{Fe}(\mathrm{III})$ and the initial concentrations are fitted values obtained by using data of Wells I3-5-6-7 (Tables 2 and 1SI). 
The favorability of sulfate reduction could exceed the favorability of crystallized iron, e.g. goethite or hematite, at commonly observed $\mathrm{Fe}^{2+}$ concentrations in the Bengali aquifers (9). In the scenario (a), it is supposed that nitrate, sulfate, and iron reduction are successive external electron acceptors, but without considering the abiotic reduction of Fe(III) by HS- Conversely, in scenario (b), the abiotic reduction of iron by $\mathrm{HS}^{-}$is considered, but without considering dissimilatory iron reduction. Comparing the results of both scenarios will determine which respiration process could account for the release of arsenic.

Iron(II) Kd sorption model. Iron and arsenic total concentrations, respectively $\mathrm{As}_{\mathrm{T}}$ and $\mathrm{Fe}_{\mathrm{T}}$, are assumed to be conserved between the two redox contrasted environments (see SI). The conservation between the two closed systems is described by the two following equations:

$$
\begin{aligned}
A s_{T} & =[A s]_{\max } \times\left(1+\sum_{i} M_{i} \times K_{d}^{i}\right) \\
F e_{T} & =\sum_{i} M_{i} \times f_{i}
\end{aligned}
$$

where $[\mathrm{As}]_{\max }$ is a high aqueous concentration of $\mathrm{As}(\mathrm{III})$ in the anoxic environment (e.g. $\left.5 \mu \mathrm{mol} / \mathrm{L}\right)$, $\mathrm{M}_{\mathrm{i}}$ the mass of the i-th Fe(II)-bearing phase (mackinawite, vivianite, magnetite, fougerite, siderite), $\mathrm{Kd}^{\mathrm{i}}$ the adsorption/partition coefficient for $\mathrm{As}(\mathrm{III})$ onto the $\mathrm{i}$-th phase, and $\mathrm{f}_{\mathrm{i}}$ the percentage of iron in the total weight of the $\mathrm{i}$-th phase. Calculation of the $\mathrm{Kd}^{\mathrm{i}}$ coefficients shows that, except for vivianite, $\mathrm{Kd}^{\mathrm{i}}$ depends strongly on $\mathrm{pH}$, in particular between $\mathrm{pH} 7$ and 7.5 which is the variation range at the Chakdaha site (28). The $\mathrm{Kd}^{\mathrm{i}}$ coefficients are calculated from the adsorbed As fraction called $\mathrm{s}$ and the i-th solid concentration called $\mathrm{d}^{\mathrm{i}}(\mathrm{g} / \mathrm{L})$ obtained from the sorption isotherms published in the literature (see Tables 1 and 3SI):

$$
K_{d}^{i}=\frac{s}{(1-s) \times d^{i}}
$$

MATLAB ${ }^{\circ}(\mathrm{R} 2006 \mathrm{~b}$, The MathWorks, Natick, MA) is used to solve the problem in cases with two, three or four sorbents. In every case, there are only two unknowns in eq 1 and in eq 2. 


\section{Results and Discussion}

Field site. A transect of simultaneously collected groundwater and aquifer solids perpendicular to the banks of the Hooghly River in Chakdaha (West Bengal, India) was used to calibrate the different models (Figures 1 and 1SI). The methods of sample collection with the needle-sampler and chemical analysis are described by van Geen et al. (29) and a description of the analytical methods is given in SI.

Two contrasted redox environments in Chakdaha subsurface. Two contrasted redox environments are distinguished in Chakdaha subsurface (13): fairly permeable sandy soils (indicated by low electromagnetic conductivity) where moderately reduced conditions prevail with low $\mathrm{Fe}(\mathrm{II}) / \mathrm{Fe}$ solid ratios $(<0.5)$, underlain by more impermeable clayey soils (indicated by high electromagnetic conductivity) where more reduced conditions prevail with high $\mathrm{Fe}(\mathrm{II}) / \mathrm{Fe}$ solid ratios $(>0.5)$. The sandy soils are also characterized by high permeability, a high concentration of sulfate ions $(>1 \mathrm{mg} / \mathrm{L}$ S), and a low arsenic concentration $(<50 \mu \mathrm{g} / \mathrm{L}$ As $)$, whereas the underlying clayey soils are characterized by low permeability, a low sulfate concentration $(<1 \mathrm{mg} / \mathrm{L} \mathrm{S})$, and a high arsenic concentration $(>100 \mu \mathrm{g} / \mathrm{L} \mathrm{As})$. This contrast is particularly observed in I7 Well, with a negative correlation $(-0.85)$ between aqueous arsenic and sulfate and a positive correlation $(+0.9)$ between aqueous arsenic and solid $\mathrm{Fe}(\mathrm{II}) / \mathrm{Fe}$ ratio. The low $\mathrm{Fe}(\mathrm{II}) / \mathrm{Fe}$ ratio is attributed to iron-oxide coatings on quartz and mica sand particles, while the high $\mathrm{Fe}(\mathrm{II}) / \mathrm{Fe}$ solid ratio may be related to $\mathrm{Fe}(\mathrm{II})$-rich minerals like Acid Volatile Sulfides (AVS; e.g. disordered mackinawite), as well as fine vivianite, siderite, fougerite and magnetite particles. These contrasted solid and aqueous environments play likely a role in the release of arsenic: the Fe(III) oxide vs. Fe(II) sulfide/carbonate solid phases correspond to high S(VI) vs. high As(III) aqueous phases. 
In order to test different scenarios, geochemical computations were performed on two closed model systems; namely a $\mathrm{Fe}(\mathrm{III})$ oxide-As(III)-SO $\mathrm{SO}_{4}$-water system known as the "Iron(III) surface complexation model" and a $\mathrm{Fe}(\mathrm{II})$ sulfide/carbonate-As(III)- $\mathrm{H}_{2} \mathrm{~S}$-water system known as the "Iron(II) Kd sorption model". In the moderately reduced environment, solid iron is assumed to be the unique sorbent and arsenite the unique sorbate. In the anoxic environment, the Fe(II)-bearing phases (magnetite, siderite, fougerite, vivianite) are potential sorbents and As(III) the unique sorbate. A "1D generic reactive transport model" is developed to simulate the transition between these two environments.

Iron(III) surface complexation model. A typical low concentration of arsenic is set to $17 \mu \mathrm{g} / \mathrm{L}$ (Table $1 \mathrm{SI}$ ) and the $\mathrm{pH}$ to 7 , the mean $\mathrm{pH}$ at Chakdaha site (14). The sorption equilibrium calculated by PHREEQC results in a total of $0.76 \mathrm{mmol}$ sorbed $\mathrm{As}(\mathrm{III}) \mathrm{L}^{-1}$ as the sum of $\equiv(\mathrm{w}) \mathrm{FeHAsO}_{3}{ }^{-}$and $\equiv(\mathrm{w}) \mathrm{FeH}_{2} \mathrm{AsO}_{3}$ (Table $\left.2 \mathrm{SI}\right)$. Assuming a porosity of 0.25 and a density of 2.62 , it corresponds to a sorbed arsenic concentration of $7.3 \mathrm{mg} \mathrm{kg}^{-1}$. The sediment extraction by phosphates dislodges by anion exchange the relatively mobile fraction of As bound to Fe oxhydroxides and, potentially, As bound to adsorbed humic acids. This fraction within the Chakdaha sediments ranged from 0.5 to $9 \mathrm{mg}$ $\mathrm{kg}^{-1}$ in Wells I3-5-6-7 (mean value $2.34 \mathrm{mg} \mathrm{kg}^{-1}$ ) (13). This surface model result is therefore consistent with the P-extractable arsenic data.

1D generic reactive transport model. The processes monitored in the above closed system are obviously not representative of those occurring in anoxic conditions: the release of arsenic depends not only on sorption interactions at local equilibrium but also on coupled reactive transport under kinetic constraints for redox sensitive elements like As, N, S, Fe. A reactive transport model was therefore developed in order to simulate a 1D flow path between the two contrasted redox systems. The calculation scheme results in smooth transitions between spatial redox zones as commonly observed in situ (30). The oxidation rate of carbon $\mathrm{C}(0)$ is assumed to be constant along the $1 \mathrm{D}$ path 
for nitrate and sulfate (see Model section). This oxidation rate is fixed to a maximum value of $2 \mathrm{mM}$ year $^{-1}$ consistent with the observed range of 1.0-1.5 mM year ${ }^{-1}$ for sulfate reduction found by Jakobsen et al. (31). Assuming a constant carbon oxidation rate in scenario (a), the iron reduction rate would be $8 \mathrm{mM} \mathrm{Fe}$ year" (one $\mathrm{e}^{-}$consumed instead of $8 \mathrm{e}^{-}$). This "high" iron bioreduction rate is consistent with our previous batch experiments with amorphous 2-line ferrihydrite (4) but the iron reduction rate for crystallized iron, e.g. goethite, is very likely below the value for the amorphous phase like 2-line ferrihydrite (32). A "low" rate of $1.5 \mathrm{mM} \mathrm{Fe} \mathrm{year}^{-1}$ was indeed fitted in scenario (a) using Well I7 (Figure 2).

The first result of (a) is that the maximum simulated concentration of As is in the range of the observed high arsenic concentrations (between 200 and $500 \mu \mathrm{g} / \mathrm{L}$ ). A sensitivity analysis to pore velocity and to the $\mathrm{Fe}(\mathrm{III})$ reduction rate illustrates however that the maximum release of arsenic depends on the balance between the flow velocity and the chemical kinetics: a "low" flow velocity or a "high" Fe(III) reduction rate will both correspond to a dissolved arsenic peak slightly above $1 \mathrm{mg} / \mathrm{L}$ (Figure 4SI). Considering the uncertainty on both parameters at the Chakdaha site, the timescales the model fits are therefore probably not significant.

In scenario (a), the spatial profiles of the redox sensitive elements, i.e. the decrease of $\mathrm{NO}_{3}{ }^{-}, \mathrm{SO}_{4}^{--}$ and the increase of $\mathrm{Fe}(\mathrm{II})$ and $\mathrm{As}(\mathrm{III})$ along the 1D vertical path, are all correctly simulated (Figure 2) but the increase in alkalinity is slightly overestimated. The simulated $\mathrm{Kd}$ of arsenic onto siderite is closed to the Kd value at $\mathrm{pH} 7$ (Table 1). The pore waters at the bottom of the profile in Wells I3-5-67 are undersaturated with respect to calcite and near from equilibrium with respect to siderite (except for I5). Combining all the samples during the period 2000-2002 showed however that the Chakdaha groundwaters are generally at local equilibrium with calcite and other carbonates (e.g. rhodochrosite, dolomite) and oversaturated with respect to siderite (14). 
In scenario (b), the aqueous As and solid $\mathrm{Fe}(2) / \mathrm{Fe}$ are not consistent with the data (Figure 3). The comparison of both scenarios demonstrates that sulfate-reducing bacteria (SRB) activity alone is not sufficient and that iron-reducing bacteria (IRB) activity is needed to explain the release of arsenic in these Wells. The comparison shows also that the simulated chemical zones are quite different: (a) shows a transition between the sulfidic and ferruginous zones; in (b), HS- reduces solid Fe(III) and thus does not accumulate despite active sulfate reduction, whilst producing $\mathrm{Fe}(\mathrm{II})$ precipitates as siderite in the sulfate reduction zone. Sulfides were not measured during this campaign but there was no significant smelling during the sampling and a sulfidic zone is therefore unlikely. Moreover, a sediment vertical profile in Cambodia revealed siderite in a deep reduced zone that is not preceded by a sulfidic zone (9). Finally, it shows that a more appropriate scenario could be the combining of both scenarios (see SI and Figure 5SI).

In the last scenario, termed (c), a concurrent dissimilatory reduction of iron and sulfate as already observed in field studies (30) or at micro-scale (33) is tested (see SI). In that case, the precipitation of $\mathrm{FeS}(\mathrm{s})$ removes $\mathrm{HS}^{-}$and $\mathrm{Fe}^{2+}$ and therefore increases the favorability of both reducers (IRB and SRB) by increasing the energy gain. The arsenic aqueous profile in (c) is consistent with the data (Figure 3). Therefore, a concurrent bacterial respiration process between IRB and SRB can not be excluded.

\section{Alternative biogeochemical mechanisms omitted in 1D model. Other (bio)geochemical} processes may consume carbonates and are not considered in this simplified model like the methanogenesis or/and the rhodochrosite precipitation (14). Moreover, our approach clearly shortcuts the multiple steps of the complex organic matter breakdown: the kinetic rate of carbon oxidation is assumed to be constant. The past decade has seen a large number of models that couple the kinetic expressions with the thermodynamic constraints, either in the fermentation step or in the terminal electron accepting reaction step. One of the most used representations is the so-called "partial redox disequilibrium" model, first developed by McNab and Narasimhan (34). The idea is to separate 
organic matter degradation into only two steps. The first step comprises hydrolyzation and fermentation, producing labile organic carbon, nutrients and inorganic carbon $\mathrm{HCO}_{3}{ }^{-}$; the produced number of inorganic moles per mole of labile organic carbon is generally unknown. The key point is that this first step limits the overall rate and that the second step is the terminal electron reactions step, which is faster and close to equilibrium.

Iron(II) Kd sorption model in Southeast Asian aquifers: a sensitivity analysis. The concentration of solid As ranges between 2 and $22 \mathrm{mg} \mathrm{kg}^{-1}$ (14). A typical sediment with about 1 wt.\% of Fe-oxides and about $2 \mathrm{mg} \mathrm{kg}^{-1}$ of solid As is considered (see SI). The one-phase systems (with a unique sorbent for arsenite) and the multiple-phase systems (with different sorbents) have been systematically investigated (Table 4SI).

In the one-phase systems, an abundance of around $15 \mathrm{wt} . \% \mathrm{Fe}$ in mackinawite is needed. This result is much higher than the observed values of AVS in Araihazar (Bangladesh), where AVS varies from 0.2 to $2 \mu \mathrm{mol} \mathrm{g}{ }^{-1}$ sediment (J. Métral, personal communication); AVS represents only 0.11 to 1.1 wt.\% iron assuming about $1 \mathrm{wt} . \%$ iron in the sediment.

Using $\mathrm{Kd}$ at $\mathrm{pH} 7$ and 7.5, a similar calculation shows that between $56 \mathrm{wt.} \%$ and $84 \mathrm{wt} \%$ iron in siderite is needed, assuming that siderite is the dominant host for arsenite. This result is a little higher than observed ratios of between $35 \%$ and $40 \%$ found in Cambodian sediments (9). The groundwater in the shallow reducing aquifers is strongly supersaturated for both vivianite $\mathrm{Fe}(\mathrm{II})_{3}\left(\mathrm{PO}_{4}\right)_{2} .8 \mathrm{H}_{2} \mathrm{O}$ and hydroxyapatite $\mathrm{Ca}_{5}\left(\mathrm{PO}_{4}\right)_{3} \mathrm{OH}$ in Bangladesh (24) and also supersaturated for vivianite in Vietnam (35). The highest concentration of $\mathrm{P}$ derived from sandy horizons of the Bengal basin was reported to be equal to $214 \mathrm{mg} \mathrm{P} / \mathrm{kg}$ (36). Assuming that vivianite is the dominant Fe-bearing host of sedimentary phosphorus, then vivianite represents only around 6 wt.\% Fe (see SI). Conversely, if we assume that vivianite is the unique sorbent for arsenite, then $87 \mathrm{wt} \%$ of iron in vivianite is needed. The conclusion is that vivianite, mackinawite and magnetite are likely not the dominant host for arsenite at 
$\mathrm{pH} 7$ and that siderite is the better candidate as the main sorbent (at least in the short list investigated in this work).

In multiple-phase systems, the residual iron is assumed to be distributed within two, three or four $\mathrm{Fe}(\mathrm{II})$-bearing phases: if mackinawite represents $1 \mathrm{wt} . \%$ of the solid iron and if furthermore the dominant hosts of arsenite are siderite and magnetite, then an abundance of 74 wt.\% siderite and 25 wt.\% magnetite are needed at pH 7 (see SI). Two possible four-phase systems are shown in Figure 4 with a similar calculated $\mathrm{Fe}(\mathrm{II}) / \mathrm{Fe}$ ratio ( 0.83 with magnetite or 0.9 with fougerite). The main conclusion for one-phase systems is still valid with multiple-phase systems: siderite seems to be the better candidate as the dominant host for arsenite at $\mathrm{pH} 7$.

Implication for arsenic heterogeneity in reducing aquifers. We first demonstrate that low concentrations of arsenic in moderately reduced zones at the Chakdaha site could be explained by a adsorption of As(III) onto solid Fe(III) oxides. We then hypothesize that the observed high concentrations of arsenic in the anoxic zones could be quantitatively interpreted by a reduction of solid Fe(III) oxides followed by sorption of $\mathrm{As}(\mathrm{III})$ on different $\mathrm{Fe}(\mathrm{II})$-bearing phases: while $\mathrm{Fe}(\mathrm{II})$ sulfide (e.g. disordered mackinawite) or vivianite are not the dominant host for arsenite, the ferrous carbonates (like siderite or/and fougerite) very likely play a major role in such reduced systems. We finally simulate the transition between the two contrasted redox zones and compare different energetically possible scenarios of arsenic release. This comparison shows that the reduction of solid iron by biogenic sulfides is not sufficient to explain this release. The reactive transport model shows also that both scenarios, assuming a successive or a concomitant sulfate and iron reduction, are consistent with the observations at Chakdaha site. 


\section{Acknowledgments}

The authors gratefully acknowledge RGNDWM, Govt. of India, IFCPAR and CNRS (EC2CO Programme) for giving financial support. One of the authors (AB) is thankful to the Bureau de Recherches Géologiques et Minières (BRGM) for supporting this publication work and to Nolwenn Croiset for helpful discussions about Phreeqc modeling.

\section{Supporting Information Available}

This information is available free of charge via the internet at http://pubs.acs.org/. 
References

1. Nickson, R.T.; McArthur, J.M.; Ravenscroft, P.; Burgess, W.G.; Ahmed, K.M. Mechanism of arsenic release to groundwater, Bangladesh and West Bengal. Appl. Geochem. 2000, 15, 403-413.

2. Islam, F.S.; Gault, A.G.; Boothman, C.; Polya, D.A.; Charnock, J.M.; Chatterjee, D.; Lloyd, J.R. Role of metal-reducing bacteria in arsenic release from Bengal delta sediments. Nature 2004, 430, 6871.

3. van Geen, A.; Rose, J.; Thoral, S.; Garnier, J.M.; Zheng, Y.; Bottero, J.Y. Decoupling of As and Fe release to Bangladesh groundwater under reducing conditions. Part II: Evidence from sediment incubations. Geochim. Cosmochim. Acta 2004, 68, 3475-3486.

4. Burnol, A.; Garrido, F.; Baranger, P.; Joulian, C.; Dictor, M.; Bodenan, F.; Morin, G.; Charlet, L. Decoupling of arsenic and iron release from ferrihydrite suspension under reducing conditions: a biogeochemical model. Geochemical Transactions 2007, 8, 12.

5. Horneman, A.; van Geen, A.; Kent, D.V.; Mathe, P.E.; Zheng, Y.; Dhar, R.K.; O'Connell, S.; Hoque, M.A.; Aziz, Z.; Shamsudduha, M. Decoupling of As and Fe release to Bangladesh groundwater under reducing conditions. Part I: Evidence from sediment profiles. Geochim. Cosmochim. Acta 2004, 68, 3459-3473.

6. Charlet, L. and Polya, D.A. Arsenic in shallow, reducing groundwaters in southern Asia: an environmental health disaster. Elements 2006, 2, 91-96.

7. Polizzotto, M.L.; Kocar, B.D.; Benner, S.G.; Sampson, M.; Fendorf, S. Near-surface wetland sediments as a source of arsenic release to ground water in Asia. Nature 2008, 454, 505-508. 
8. Kocar, B.D.; Polizzotto, M.L.; Benner, S.G.; Ying, S.C.; Ung, M.; Ouch, K.; Samreth, S.; Suy, B.; Phan, K.; Sampson, M.; Fendorf, S. Integrated biogeochemical and hydrologic processes driving arsenic release from shallow sediments to groundwaters of the Mekong delta. Appl. Geochem. 2008, 23, 3059-3071.

9. Kocar, B.D. and Fendorf, S. Thermodynamic Constraints on Reductive Reactions Influencing the Biogeochemistry of Arsenic in Soils and Sediments. Environ. Sci. Technol. 2009, 43, 4871-4877.

10. Eiche, E.; Neumann, T.; Berg, M.; Weinman, B.; van Geen, A.; Norra, S.; Berner, Z.; Trang, P.T.K.; Viet, P.H.; Stüben, D. Geochemical processes underlying a sharp contrast in groundwater arsenic concentrations in a village on the Red River delta, Vietnam. Appl. Geochem. 2008, 23, 31433154.

11. van Geen, A.; Zheng, Y.; Goodbred, S.; Horneman, A.; Aziz, Z.; Cheng, Z.; Stute, M.; Mailloux, B.; Weinman, B.; Hoque, M.A.; Seddique, A.A.; Hossain, M.S.; Chowdhury, S.H.; Ahmed, K.M. Flushing History as a Hydrogeological Control on the Regional Distribution of Arsenic in Shallow Groundwater of the Bengal Basin. Environ. Sci. Technol. 2008, 42, 2283-2288.

12. Radloff, K.A.; Manning, A.R.; Mailloux, B.; Zheng, Y.; Moshiur Rahman, M.; Rezaul Huq, M.; Ahmed, K.M.; Geen, A.v. Considerations for conducting incubations to study the mechanisms of As release in reducing groundwater aquifers. Appl. Geochem. 2008, 23, 3224-3235.

13. Metral, J.; Charlet, L.; Bureau, S.; Mallik, S.; Chakraborty, S.; Ahmed, K.; Rahman, M.; Cheng, Z.; van Geen, A. Comparison of dissolved and particulate arsenic distributions in shallow aquifers of Chakdaha, India, and Araihazar, Bangladesh. Geochemical Transactions 2008, 9, 1. 
14. Nath, B.; Chakraborty, S.; Burnol, A.; Stüben, D.; Chatterjee, D.; Charlet, L. Mobility of arsenic in the sub-surface environment: An integrated hydrogeochemical study and sorption model of the sandy aquifer materials. Journal of Hydrology 2009, 364, 236-248.

15. Thinnappan, V.; Merrifield, C.M.; Islam, F.S.; Polya, D.A.; Wincott, P.; Wogelius, R.A. A combined experimental study of vivianite and As (V) reactivity in the $\mathrm{pH}$ range 2-11. Appl. Geochem. 2008, 23, 3187-3204.

16. Jönsson, J. and Sherman, D.M. Sorption of As(III) and $\operatorname{As}(\mathrm{V})$ to siderite, green rust (fougerite) and magnetite: Implications for arsenic release in anoxic groundwaters. Chemical Geology 2008, 255, 173-181.

17. Wolthers, M.; Charlet, L.; van Der Weijden, C.H.; van der Linde, P.R.; Rickard, D. Arsenic mobility in the ambient sulfidic environment: Sorption of arsenic(V) and arsenic(III) onto disordered mackinawite. Geochim. Cosmochim. Acta 2005, 69, 3483-3492.

18. Parkhurst, D.L.; Appelo, C.A.J. User's guide to Phreeqc (version 2)- a computer program for speciation, batch-reaction, one-dimensional transport, and inverse geochemical calculation; USGS: Denver, 1999.

19. Ball, J.W.; Nordstrom, D.K. User's Manual for WATEQ4F, with Revised Thermodynamic Data Base and Test Cases for Calculating Speciation of Major, Trace, and Redox Elements in Natural Waters; USGS: Denver, 1991.

20. Dixit, S. and Hering, J.G. Comparison of arsenic(V) and arsenic(III) sorption onto iron oxide minerals: Implications for arsenic mobility. Environ. Sci. Technol. 2003, 37, 4182-4189.

21. Schecher, W.D.; McAvoy, D.C. MINEQL+, V4.5, Users Manual; Hallowell: ME, 1998. 
22. Dzombak, D.A.; Morel, F.M.M. Surface Complexation Modeling: Hydrous Ferric Oxide; John Wiley \& Sons: New York, 1990.

23. Campbell, K.M.; Malasarn, D.; Saltikov, C.W.; Newman, D.K.; Hering, J.G. Simultaneous Microbial Reduction of Iron(III) and Arsenic(V) in Suspensions of Hydrous Ferric Oxide. Environ. Sci. Technol. 2006, 40, 5950-5955.

24. Swartz, C.H.; Blute, N.K.; Badruzzman, B.; Ali, A.; Brabander, D.; Jay, J.; Besancon, J.; Islam, S.; Hemond, H.F.; Harvey, C.F. Mobility of arsenic in a Bangladesh aquifer: Inferences from geochemical profiles, leaching data, and mineralogical characterization. Geochim. Cosmochim. Acta 2004, 68, 4539-4557.

25. Hunter, K.S.; Wang, Y.; Van Cappellen, P. Kinetic modeling of microbially-driven redox chemistry of subsurface environments: coupling transport, microbial metabolism and geochemistry. $J$. Hydrol. (Amst. ) 1998, 209, 53-80.

26. Curtis, G.P. Comparison of approaches for simulating reactive solute transport involving organic degradation reactions by multiple electron acceptors. Computers \& Geosciences 2003, 29, 319-329.

27. Heimann, A.; Jakobsen, R.; Blodau, C. Energetic Constraints on H2-Dependent Terminal Electron Accepting Processes in Anoxic Environments: A Review of Observations and Model Approaches. Environ. Sci. Technol. 2010, 44, 24-33.

28. Charlet, L.; Chakraborty, S.; Appelo, C.A.J.; Roman-Ross, G.; Nath, B.; Ansari, A.A.; Lanson, M.; Chatterjee, D.; Mallik, S.B. Chemodynamics of an arsenic "hotspot" in a West Bengal aquifer: A field and reactive transport modeling study. Appl. Geochem. 2007, 22, 1273-1292. 
29. van Geen, A.; Protus, T.; Cheng, Z.; Horneman, A.; Seddique, A.A.; Hoque, M.A.; Ahmed, K.M. Testing Groundwater for Arsenic in Bangladesh before Installing a Well. Environ. Sci. Technol. 2004, 38, 6783-6789.

30. Postma, D. and Jakobsen, R. Redox zonation; equilibrium constraints on the Fe(III)/ $\mathrm{SO}_{4}$ reduction interface. Geochim. Cosmochim. Acta 1996, 60, 3169-3175.

31. Jakobsen, R. and Cold, L. Geochemistry at the sulfate reduction-methanogenesis transition zone in an anoxic aquifer-A partial equilibrium interpretation using 2D reactive transport modeling. Geochim. Cosmochim. Acta 2007, 71, 1949-1966.

32. Bonneville, S.; Van Cappellen, P.; Behrends, T. Microbial reduction of iron(III) oxyhydroxides: effects of mineral solubility and availability. Chem. Geol. 2004, 212, 255-268.

33. Motelica-Heino, M.; Naylor, C.; Zhang, H.; Davison, W. Simultaneous Release of Metals and Sulfide in Lacustrine Sediment. Environ. Sci. Technol. 2003, 37, 4374-4381.

34. McNab, W.W., J. and Narasimhan, T.N. Modeling reactive transport of organic compounds in groundwater using a partial redox disequilibrium approach. Water Resour. Res. 30, 2619-2635.

35. Postma, D.; Larsen, F.; Minh Hue, N.T.; Duc, M.T.; Viet, P.H.; Nhan, P.Q.; Jessen, S. Arsenic in groundwater of the Red River floodplain, Vietnam: Controlling geochemical processes and reactive transport modeling. Geochim. Cosmochim. Acta 2007, 71, 5054-5071.

36. BGS; DPHE Arsenic contamination of groundwater in Bangladesh; D. G. Kinniburgh, P. L. Smedley, Eds; BGS: Keyworth, 2001.

37. Afonso, M.D. and Stumm, W. Reductive Dissolution of Iron(III) (Hydr)oxides by HydrogenSulfide. Langmuir 1992, 8, 1671-1675. 
38. Poulton, S.W. Sulfide oxidation and iron dissolution kinetics during the reaction of dissolved sulfide with ferrihydrite. Chem. Geol. 2003, 202, 79-94.

39. Wolthers, M.; Charlet, L.; van Der Linde, P.R.; Rickard, D.; van Der Weijden, C.H. Surface chemistry of disordered mackinawite (FeS). Geochim. Cosmochim. Acta 2005, 69, 3469-3481.

40. Bruno, J.; Wersin, P.; Stumm, W. On the influence of carbonate in mineral dissolution: II. The solubility of $\mathrm{FeCO} 3$ (s) at $25^{\circ} \mathrm{C}$ and 1 atm total pressure. Geochim. Cosmochim. Acta 1992, 56, 11491155.

41. Al-Borno, A. and Tomson, M. The temperature dependence of the solubility product constant of vivianite. Geochimica et Cosmochimica Acta 1994, 58, 5373-5378. 
Table 1. Reactions used in "Iron(III) surface complexation model" and "Iron(II) Kd sorption model'

\begin{tabular}{|c|c|c|}
\hline "Iron(III) surface complexation model" & $\begin{array}{c}\log \mathrm{K} \\
\left(\mathrm{I}=\mathbf{0} \mathrm{M}, 25^{\circ} \mathrm{C}\right)\end{array}$ & Reference \\
\hline$\overline{\mathrm{H}_{3} \mathrm{AsO}_{3}{ }^{\circ}=\mathrm{H}_{2} \mathrm{AsO}_{3}{ }^{-}+\mathrm{H}^{+}}$ & -9.22 & $(21)$ \\
\hline $\mathrm{H}_{2} \mathrm{AsO}_{3}{ }^{-}=\mathrm{HAsO}_{3}{ }^{2-}+\mathrm{H}^{+}$ & -12.11 & $(21)$ \\
\hline $\mathrm{HAsO}_{3}{ }^{2-}=\mathrm{AsO}_{3}{ }^{3-}+\mathrm{H}^{+}$ & -13.41 & $(21)$ \\
\hline$\equiv(\mathrm{w}) \mathrm{FeOH}+\mathrm{H}^{+}=\equiv(\mathrm{w}) \mathrm{FeOH}_{2}^{+}$ & 7.29 & (22) \\
\hline$\equiv(\mathrm{w}) \mathrm{FeOH}=\equiv(\mathrm{w}) \mathrm{FeO}^{-}+\mathrm{H}^{+}$ & -8.93 & (22) \\
\hline$\equiv(\mathrm{w}) \mathrm{FeOH}+\mathrm{AsO}_{3}{ }^{3-}+3 \mathrm{H}^{+}=\equiv(\mathrm{w}) \mathrm{FeH}_{2} \mathrm{AsO}_{3}+\mathrm{H}_{2} \mathrm{O}$ & 38.76 & $(20)$ \\
\hline$\equiv(\mathrm{w}) \mathrm{FeOH}+\mathrm{AsO}_{3}{ }^{3-}+2 \mathrm{H}^{+}=\equiv(\mathrm{w}) \mathrm{FeHAsO}_{3}{ }^{-}+\mathrm{H}_{2} \mathrm{O}$ & 31.87 & $(20)$ \\
\hline$\equiv(\mathrm{w}) \mathrm{FeOH}+\mathrm{HS}^{-}=\equiv(\mathrm{w}) \mathrm{FeS}^{-}+\mathrm{H}_{2} \mathrm{O}$ & 5.3 & $(37)$ \\
\hline$\equiv(\mathrm{w}) \mathrm{FeOH}+\mathrm{HS}^{-}+\mathrm{H}^{+}=\equiv(\mathrm{w}) \mathrm{FeHS}+\mathrm{H}_{2} \mathrm{O}$ & 10.82 & $(37)$ \\
\hline
\end{tabular}

"Iron(II) Kd sorption model"

Kd in $L / g$

at pH 7 (7.5)

Reference

$\mathrm{H}_{3} \mathrm{AsO}_{3}$ sorption on mackinawite

$2(2)$

(17)

$\mathrm{H}_{3} \mathrm{AsO}_{3}$ sorption on siderite

$0.267(0.4)$

(16)

$\mathrm{H}_{3} \mathrm{AsO}_{3}$ sorption on magnetite

$0.081(0.215)$

(16)

$\mathrm{H}_{3} \mathrm{AsO}_{3}$ sorption on fougerite

$0.095(0.57)$

(16)

$\mathrm{H}_{3} \mathrm{AsO}_{3}$ sorption on vivianite

$0.18(0.18)^{\mathrm{a}}$

(15)

a experimental $\mathrm{Kd}$ for $\mathrm{As}(\mathrm{V})$ is assumed valid for $\mathrm{As}(\mathrm{III})$ 
Table 2. Biogeochemical reactions included in the " $1 \mathrm{D}$ generic reactive transport model"

\begin{tabular}{|c|c|c|c|}
\hline $\begin{array}{l}\text { Terminal electron accepting processes } \\
\text { (biotic pathways) }\end{array}$ & {$[\mathbf{E A}]_{\lim }{ }^{\mathbf{b}}$} & $\begin{array}{c}\text { Maximum reduction rate } \\
(\mathrm{C}(0) \text { oxidation rate } \\
\text { mM/year }\end{array}$ & Reference \\
\hline $\begin{array}{l}\text { Denitrifrication } \\
4 / 5 \mathrm{NO}_{3}^{-}+1 / 2 \mathrm{C}_{2} \mathrm{H}_{3} \mathrm{O}_{2}^{-}+3 / 10 \mathrm{H}^{+} \rightarrow 2 / 5 \mathrm{~N}_{2}+\mathrm{HCO}_{3}{ }^{-}+1 / 5 \mathrm{H}_{2} \mathrm{O}\end{array}$ & $14 \mathrm{mg} / \mathrm{L}^{\mathrm{b}}$ & $8 / 5\left(2^{a}\right)$ & see text \\
\hline $\begin{array}{l}\text { Sulfate reduction } \\
1 / 2 \mathrm{SO}_{4}{ }^{2-}+1 / 2 \mathrm{C}_{2} \mathrm{H}_{3} \mathrm{O}_{2}^{-}+1 / 2 \mathrm{H}^{+} \rightarrow 1 / 2 \mathrm{H}_{2} \mathrm{~S}+\mathrm{HCO}_{3}^{-}\end{array}$ & $0.5 \mathrm{mg} / \mathrm{L}^{\mathrm{b}}$ & $1\left(2^{a}\right)$ & $(31)$ \\
\hline $\begin{array}{l}\text { Iron reduction } \\
4 \mathrm{FeOOH}+1 / 2 \mathrm{C}_{2} \mathrm{H}_{3} \mathrm{O}_{2}^{-}+15 / 2 \mathrm{H}^{+} \rightarrow \mathrm{HCO}_{3}^{-}+4 \mathrm{Fe}^{2+}+6 \mathrm{H}_{2} \mathrm{O}\end{array}$ & $42 \mathrm{mM}^{\mathrm{b}}$ & $\begin{array}{l}\text { "High rate" } 8\left(2^{\mathrm{a}}\right) \\
\text { "Low rate" } 1.5\left(0.375^{\mathrm{a}}\right)\end{array}$ & see text \\
\hline Secondary redox reaction (abiotic pathway) & & Kinetic rate $\mathrm{mn}^{-1}$ & \\
\hline $\mathrm{HS}^{-}+5 \mathrm{H}^{+}+2 \mathrm{FeOOH} \rightarrow \mathrm{S}^{\circ}+2 \mathrm{Fe}^{2+}+4 \mathrm{H}_{2} \mathrm{O}$ & & $\mathrm{k}=1 / 40$ & $(38)$, see SI \\
\hline Precipitation reactions (non redox) & $\log K$ & & \\
\hline Mackinawite $+\mathrm{H}^{+}=\mathrm{Fe}^{2+}+\mathrm{HS}^{-}$ & -2.95 & & (39) \\
\hline Siderite $+\mathrm{H}^{+}=\mathrm{Fe}^{2+}+\mathrm{HCO}_{3}^{-}$ & -0.47 & & (40) \\
\hline Vivianite $=3 \mathrm{Fe}^{2+}+2 \mathrm{PO}_{4}^{3-}+8 \mathrm{H}_{2} \mathrm{O}$ & -35.77 & & (41) \\
\hline Calcite $+\mathrm{H}^{+}=\mathrm{Ca}^{2+}+\mathrm{HCO}_{3}^{-}$ & 1.85 & & (19) \\
\hline
\end{tabular}

Adsorption reactions

$\mathrm{H}_{3} \mathrm{AsO}_{3}$ sorption on mackinawite and siderite
Kinetic rate $\mathrm{s}^{-1}$

$\mathrm{k}=1 / 100$

see Table 1 


\section{FIGURE CAPTIONS}

FIGURE 1. Google Earth satellite image [http://earth.google.com/] of the study area (Chakdaha) in West Bengal, India. Symbols indicate the positions of needle-sampler profiles I1-I7 along the Hooghly River transect. Because of the oxidation-reduction (redox) conditions, the data material of this study is restricted to the Wells I7, I6, I5, I3 indicated by the red symbols (see SI).

FIGURE 2. Comparison of the results of the simulated scenario (a) with the porewater profiles of As, $\mathrm{Fe}, \mathrm{S}, \mathrm{HCO}_{3}^{-}$and $\mathrm{NO}_{3}{ }^{-}$from the Well $\mathrm{I} 7$ (open square), Well I6 (open delta), Well I5 (open circle), Well $\mathrm{I} 3$ (open diamond). $\mathrm{S}$ is calculated from the $\mathrm{SO}_{4}{ }^{2-}$ determinations by ion chromatography (13). In order to compare all the Wells data with the $1 \mathrm{D}$ model, a reference depth $\mathrm{Z} 0$ is chosen for each Well (see Table 1SI). The solid lines represent aqueous predictions at the time where aqueous As reached its maximum value in scenario (a) with the "low" iron reduction rate (see Table 2 and main text). The simulated Saturation Indices (SI) of calcite and siderite are deduced from the alkalinities measured by titration. The dotted line is the simulated $\mathrm{Kd}$ of As onto siderite.

FIGURE 3. Comparison of the depth distribution of chemical zones and respiration processes in three scenarios (see text for details): in scenario (a), nitrate reduction precedes successive dissimilatory sulfate and Fe reduction; in scenario (b), nitrate reduction precedes sulfate reduction and abiotic Fe reduction by $\mathrm{HS}^{-}$; in scenario (c), nitrate reduction precedes concomitant dissimilatory Fe and sulfate reduction (see SI). In scenario (a), the dissimilatory Fe(III) reduction rate is fixed to the "low value" of $1.5 \mathrm{mM} /$ year. In the left-hand graphs, $\mathrm{S}(-\mathrm{II}), \mathrm{Fe}(\mathrm{II})$ and $\mathrm{As}(\mathrm{III})$ are represented at the time when aqueous As(III) reached its maximum value in each scenario, by the dashed-dotted, dashed and solid lines, respectively. In the right-hand graphs, solid Fe(III), mackinawite, siderite concentrations and $\mathrm{Fe}(\mathrm{II}) / \mathrm{Fe}$ molar ratio are shown at this time with the dotted, dashed-dotted, dashed and solid lines, respectively. The aqueous As and $\mathrm{Fe}(\mathrm{II}) / \mathrm{Fe}$ ratios of Wells I3, I5, I6, I7 are also shown with open square, delta, circle and diamond, respectively. In all scenarios, vivianite is not allowed to precipitate. 
FIGURE 4. Two possible four-phase systems calculated in "Iron(II) Kd sorption model" at pH 7: mackinawite represents 1 wt.\% Fe, vivianite 6 wt.\% Fe (see SI) and the other possible phases are siderite and magnetite (or fougerite). 


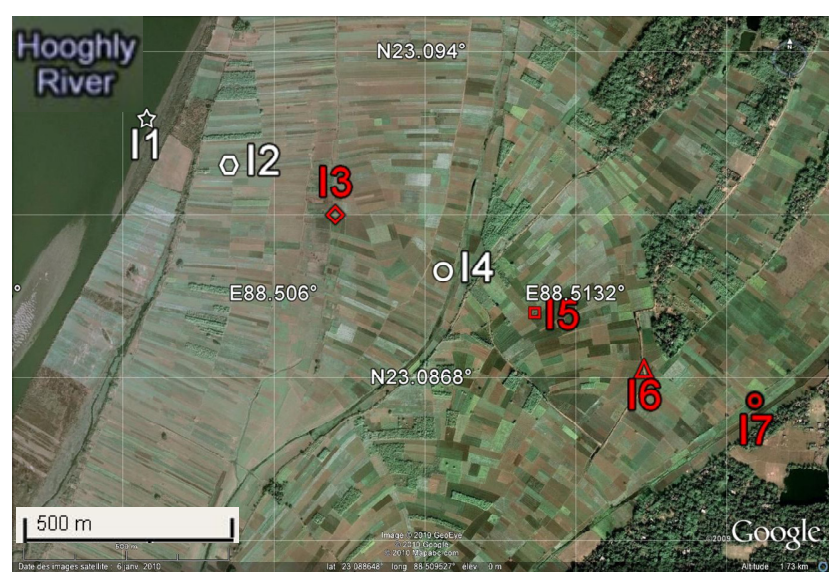

FIGURE 1 


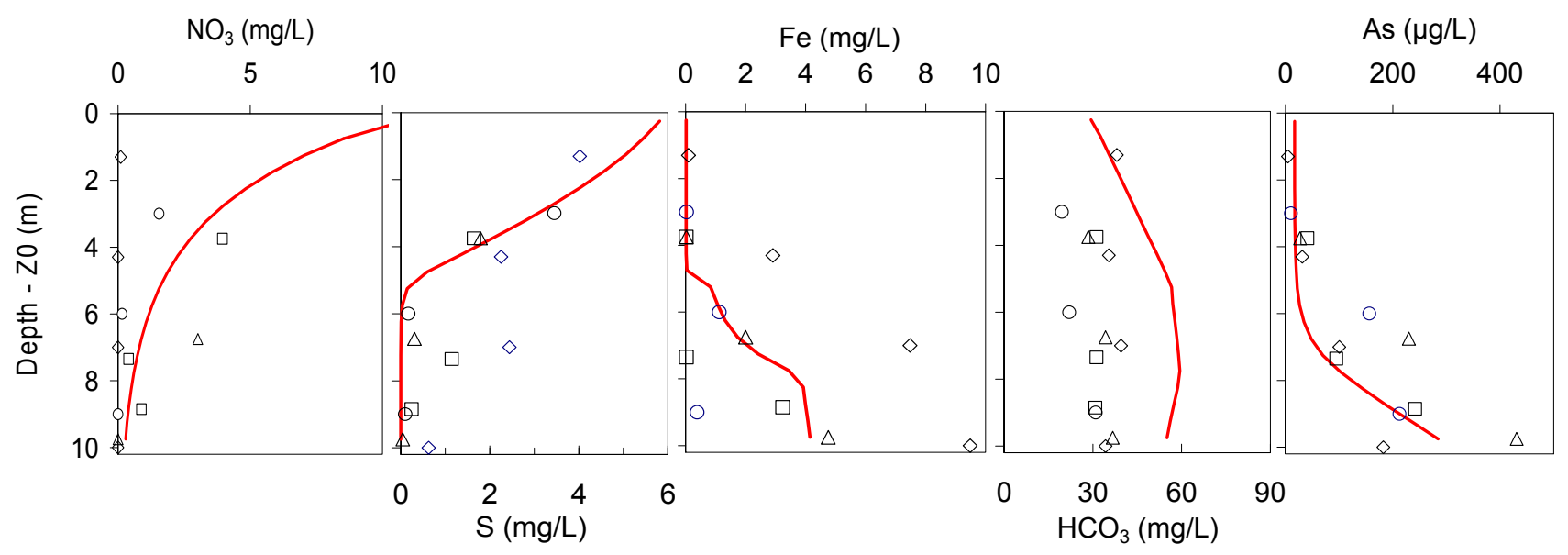

SI Siderite and $\mathrm{Kd}$
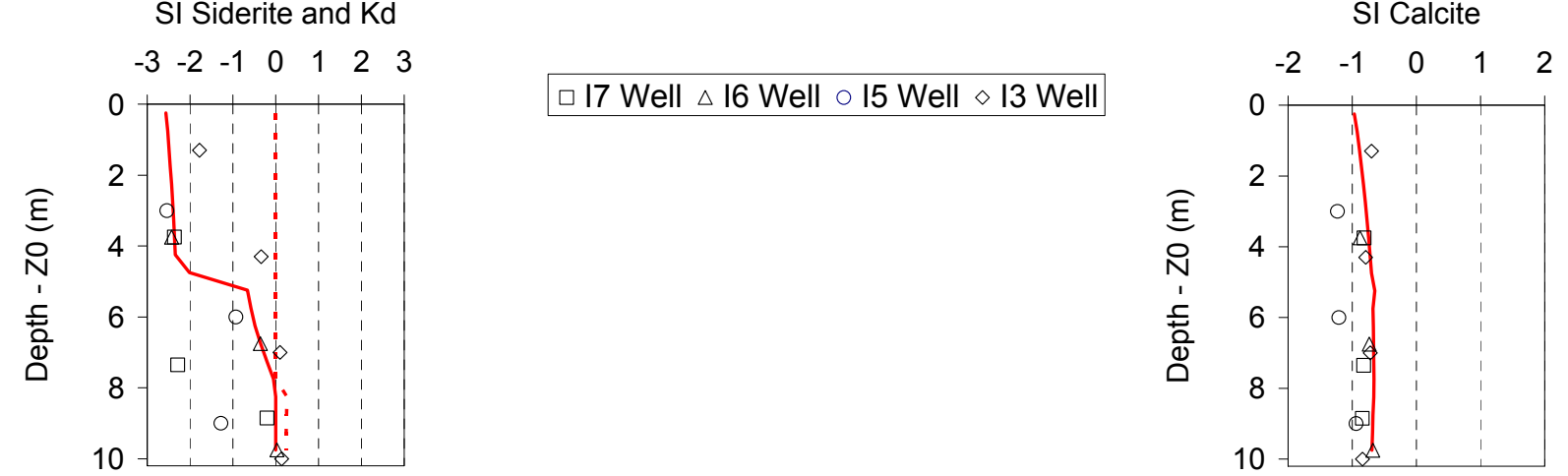

FIGURE 2 


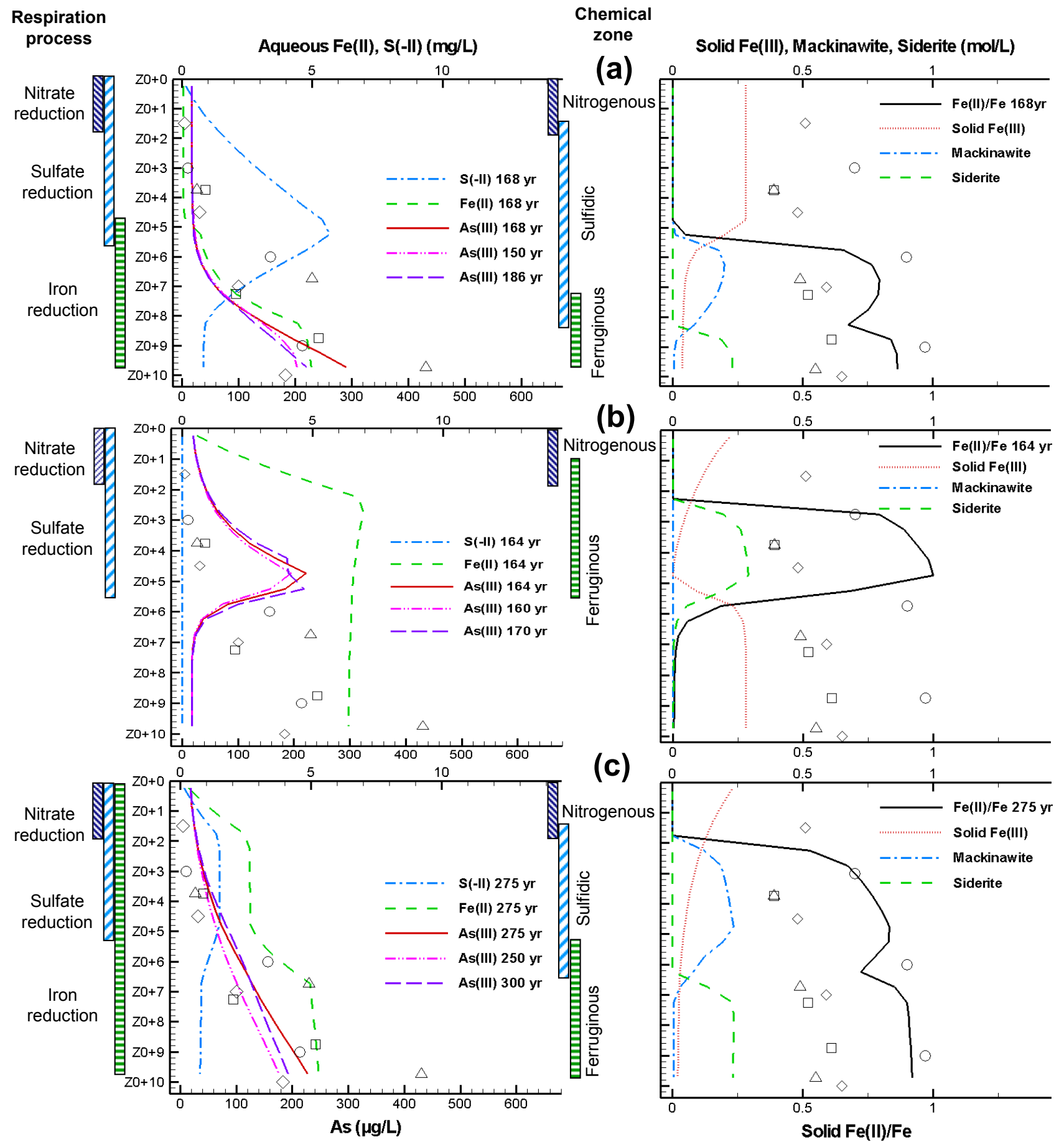

FIGURE 3 


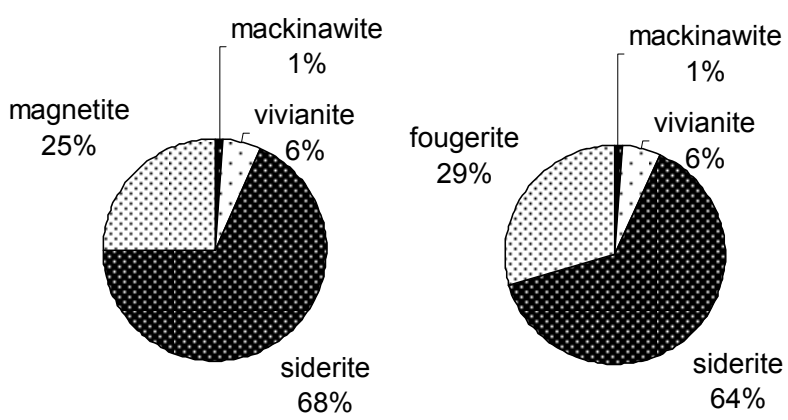

FIGURE 4 
Brief: The nature and distribution of iron-bearing minerals has a prominent impact on arsenic mobilization in Southeast Asian groundwater 